\title{
Remembering "Andy" Aines: A look back at his call for a national STI policy
}

\author{
W. David Penniman* \\ Columbus, $\mathrm{OH}, \mathrm{USA}$
}

\begin{abstract}
A commemoration is presented of the passing 25 years ago of Andrew A. Aines, a pioneer and staunch advocate for a rational national information policy and approach to the dissemination of scientific and technical information. Included in this recognition of his efforts is information on an unfinished manuscript of major proportions covering the post-World War II efforts to create such a national policy. This manuscript includes a detailed history of the establishment and evolution of the Committee on Scientific and Technical Information (COSATI) and is available on the Internet Archive.
\end{abstract}

Keywords: National information policy, STI, scientific and technical information, COSATI, committee on scientific and technical information, scientific and technical communication

\section{Introduction}

It has been exactly 25 years since the passing of Andrew Adolphe Aines, (Colonel, U.S. Army, retired). Known as Andy to his friends of which he had many, this exceptional "officer and a gentleman" should be remembered by all information professionals as an unwavering champion for a national (and rational) information policy around scientific and technical information (STI), its production and distribution.

When he died in September of 1996 he left behind a legacy of written and spoken arguments for the importance of our scientific and technical knowledge, present and future and the urgency of managing this resource in the national interest. He also left behind an unfinished manuscript for a major chronicle of the efforts of many to make a rational national policy a reality. And that is where my role came into play. Somehow, I inherited a box of papers representing a portion of this unfinished manuscript. On a hunch that more existed beyond my one box of manuscript drafts, my wife and I spent several days at the University of Maryland Hornbake Library digging through 117 boxes of archival material taken from Andy's office at the time of his passing. What we found scattered among those boxes was much more than additions to the unfinished manuscript, which totaled close to 1000 typewritten pages. We found, as well, most of his "professional history" including an unattributed, biography that captures in just a few hundred words the highlights his life and work.

Presented here is that biography as well as some key excerpts from the manuscript he left for posterity. Upon my retirement from professional life, I made a personal commitment to seeing his unfinished opus made available to the broader information community. In addition to this article, the entire unfinished manuscript has been deposited with the Internet Archive [1].

\footnotetext{
*Corresponding author: W. David Penniman, Retired, 4457 Rosemary Parkway, Columbus, OH 43214, USA. Tel.: +1 716 208 6373; E-mail: dave_penniman@yahoo.com.
} 
While efforts continue to make our national resource of scientific and technical information available to all who can benefit at a reasonable cost, his frustration expressed in his manuscript with the slow progress of that time would only be magnified with the current state of affairs.

\section{Andrew A. Aines - a biography (and perhaps an autobiography)}

Colonel Andrew A. Aines (U.S. Army retired), an apostle of the new information age, has had, for more than 30 years, by deed and action, a major forward-looking leadership role in the development of our national information programs. As a senior government official, his keen understanding of the geopolitical necessity and international importance of strong national information programs has provided the basis for U.S. policy in this area.

Ever since Colonel Aines planned, organized, and directed, in 1958, the Army information program, he has pioneered in the development and application of novel and effective approaches to cooperative Government/non-Government information activities. Always present in his efforts has been a national approach that far transcends his important Government role. It is this approach, combined with his comprehensive vision of future policy and political developments that have enabled. him, in international intergovernmental meetings, to represent best the broad interests of the U.S. information community. In OECD meetings his " $3 \mathrm{C}$ " approach - content (information), computer, and communication - became the accepted basis for promulgating information policy.

Colonel Aines has always been a teacher able to glimpse beyond the mountains, and he has always taken great pride in his visionary and creative leadership. He is persistent and tenacious in his views and graciously articulate in expressing them. Above all, he is a patriot and is dedicated to public service. His military career spanned 25 years and his Federal Civilian Service, 16 additional years.

In 1963, Colonel Aines was assigned to Lieutenant General Ely, Deputy Assistant Secretary of Defense, ODDR \& E. General Ely also served as Chairman, Committee for Scientific and Technical Information (COSATI) of the Federal Council for Science and Technology (FCST), and Colonel Aines served as the Executive Secretary. Several months later, Dr. Donald Hornig President Johnson's Science Advisor, decided to move COSATI from its DoD quarters to the Office of Science and Technology (OST) in the Executive Office Building next to the White House.

COSATI was the result of discussions beginning in 1958 shortly after the launch of Sputnik by the Russians. United States officials, among other concerns regarding our apparent lag in technological innovation, determined there were impediments to the effective communication of scientific and technical information among our various government agencies. Discussions of how to address this issue resulted subsequently in the establishment of COSATI in 1964. (The committee was later abandoned as described in Colonel Aines detailed manuscript.)

Dr. Hornig asked Colonel Aines to remain as the Executive Secretary of COSATI, but in a civilian capacity. This assignment required Colonel Aines to retire from the military after 25 years of service. Before his retirement, he was awarded the Legion of Merit Medal for his outstanding leadership service to the Army Technical Information Program. In 1966, Colonel Aines was appointed Chairman of COSATI by Dr. Hornig, the President's Science Advisor and Chairman, FCST. In this capacity, he became the National Focal Point, nationally and internationally, for scientific and technical information matters.

In 1971, the Science Information Council of the National Science Foundation recommended to Dr. Edward David, President Nixon's Science Advisor, that COSATI be moved to the National Science Foundation (NSF). Because COSATI was assigned to the NSF Office of Science Information Service, the Director of that Office became the Chairman of COSATI. Colonel Aines retained his important role in the 
NSF information program until 1978, when he transferred to the Department of Defense as Director, DoD Scientific and Technical Information. In 1980, he became Director of Technical Information, Department of Energy for 5 years, retiring from the Federal Service in 1985.

After the demise of COSATI in 1973, Col. Aines organized the Federal Information Manager's Group to keep the members fully informed in regular meetings on subjects of current interest and value to them in managing their information programs. Since 1985, Colonel Aines has been writing a multivolume history covering the golden years of the Federal Information Programs and, at the same time has been continuing his important work with the Federal Information Manager's Group. He is a scholarly writer of more than 500 articles or chapters of books and has been an honored speaker in more than 100 forums across the country. Colonel Aines currently writes a regular column for Government Computer News and INFOSCOPE. He continues to give of himself fully and unselfishly in furthering the goals of the U.S. information and library communities.

\section{The unfinished opus - a call for a (rational) national policy on STI}

Andy's dream of treating our scientific and technical information as a valued national resource just as we treat other natural resources - for the betterment of our country and its people is expressed throughout his work. The book he was creating captured the history of this resource from the end of World War II up through the mid 1990's. More importantly, it also contained a road map showing what was left to be accomplished if a robust national approach to the ready sharing of information was to be achieved.

\subsection{Chapter 1}

Upon the completion of the first chapter of his book (which in length could have been a book, including nearly 300 typewritten pages), Andy stated in a cover letter dated October 19, 1983, to Dr. Harold Schoolman, acting director of NLM where Andy was housed as a Scholar in Residence, "At long last... I have completed the first chapter of my book on the history of Federal STI since World War II. (This chapter will) set the stage for the following chapters, especially the last one, which will feature what I believe needs to be done in the future."

Ending on a hopeful note he closes Chapter 1 with the following: "Both government and the private information sectors are expected to play vigorous and cooperative roles in the decade ahead to perfect Federal and national science communications. Learning how to work together in the national interest is now the order of the day." [1, Chapter 1 Section 1.18] And it still is!

However, in a later chapter he is less hopeful when he states: "What has not happened in recent years is the development of a well-organized program that would create a pool of trained science and information managers to provide vigorous Federal STI leadership at White House and Federal agencies and for coordination and cooperation between the public and private information sectors at home and abroad." [1, Chapter 6, Section 6.0.1].

\subsection{Chapter 2}

While his opening chapter is impressive in content and completeness, it pales in comparison to his next chapter of almost 700 typewritten pages tracing in great detail the behind-the-scenes machinations involving government efforts to "manage information resources" and includes considerable information on the creation and operation of the committee on Scientific and Technical Information (COSATI). No 
one had greater insight into this arena, especially concerning COSATI, than Andy, who served as secretary and then chair of the committee.

It would be difficult to select just a few salient quotes from this extensive chapter, but one leaps out as indicative of the underlying tensions that existed throughout the life of COSATI; "(There is a) battle going on between those who welcomed the arrival of organized Federal STI programs as an opportunity and evidence of Federal government leadership and responsibility and those who felt less comfortable with the emergence of the technical literature as a bedfellow of the refereed scientific journal." [1, Chapter 2 , Section 2.1].

\subsection{Chapter six}

Moving to the final two chapters of this unfinished work, there is some added perspective on the evolving landscape for STI. For example, in the second to last chapter, Andy states; "During the period when COSATI was alive, there was a conscious effort on the part of the White House and Congress to require the orderly growth of Federal STI and communication activities. With funds provided by the Congress for $R \& D$, a fraction thereof was used for studies and other research to improve the individual STI programs of agencies, as well as government wide STI programs".

Reflecting on conditions prior to and after the demise of COSATI, he further noted that this had the positive result that "... several Federal information managers formed an interaction group called CENDI, an acronym made up of names of the involved agencies: Commerce, Energy, NASA, DOD, and I for information [1, Chapter 6, Section 6.4.2].

As a final epitaph for COSATI, he stated that "the forces that originally propelled COSATI into its national information system program are still operating. They include the need for: more orderly growth of all STI services; improved, less duplicative STI services; more rapid STI access and information flow for a growing army of users, much improved utilization of R\&D results to expedite technology transfer; more cooperation between the public and private information sectors; substantial increase of combined STI research and studies; and increased efficiency and economy in STI system development and operations" [1, Chapter 6, Section 6.10.2].

\subsection{Chapter 7}

In his final chapter, Andy chose a stinging quote from Peter Drucker to set the stage: "I see government as obese and muscle-bound and having lost its capacity to perform... [2]".

Andy sounds a more hopeful note when he writes regarding this quote: "Nevertheless, most Americans believe that their government and their national economy have sufficient resiliency to keep the dream alive, and that with our enlightened leadership and dedicated citizens, we will forge ahead. However, we are not going to succeed, unless we apply more intelligent thought to solve our problems. This is why I believe that science communications will have to be given a new look in this mixed-up era of potent electronic communication, unparalleled investments in Federal and private sector R\&D, growing mountains of unused or unusable scientific and technical information and data, under-developed technology transfer mechanisms, gridlocked transportation in many of our cities, almost intractable social problems, and very much more. Do we have any other option?" [1, Chapter 7.1, 3rd paragraph].

In the concluding sentence of the final chapter of his unfinished work, Andy states: "While our devotion to a policy of let-it-all-hang-out information dissemination makes it necessary, though uncomfortable, to reveal all our blemishes to a fascinated world, we must counterbalance the negative fall-out with a 
program to skillfully use the tools of the Information Age to help solve our problems and move on to greater conquests for the United States and the democratic ideal." [1, Chapter 7, final sentence].

\section{Conclusion}

Andy continued this "unfinished work" despite the constant pain from unsuccessful back surgery. For Andy, this mission was not just the manuscript he left behind but a bold challenge to future generations. While the manuscript he did not live to complete will reside in the Internet Archive accessible for all, the real "unfinished work" both literally and figuratively remains for a new generation to complete. His vision that important scientific and technical information would be readily available to the nation's scientists and engineers is now a shared vision by many, with the hope of success made possible by a robust scientific communications infrastructure, a growing democratization and openness of science, and an evolution in publishing as epitomized by the Open Access movement [3]. Andy would be smiling but would surely say "Get going folks. Time is wasting!"

\section{References}

[1] https://archive.org/details/aines-andrew-sti-policy-manuscript.

[2] A.P. Sanoff, A conversation with Peter Drucker, nobody believes any more that government delivers. U.S. News \& world Report. December 21, 1981, 74-75.

[3] J. Brainard, Open access takes flight, Science 371(6524) (2021), 16-20. 